\title{
Pengaruh Integrasi Rantai Pasokan Terhadap Keunggulan Bersaing Melalui Kinerja Rantai Pasokan pada Peternak Sapi Perah
}

\author{
Yun Yun ${ }^{1}$. Asep Kurniawan ${ }^{2}$ \\ Jurusan Manajemen, Fakultas Ekonomi dan Bisnis, Universitas Jenderal Achmad Yani, Cimahi, Indonesia ${ }^{1}$ \\ Jurusan Manajemen, Fakultas Ekonomi dan Bisnis, Universitas Jenderal Achmad Yani, Cimahi, Indonesia ${ }^{2}$
}

\begin{abstract}
Livestock products, especially cow's milk, have related constraints that are easily damaged so that they require more handling. Especially in cold supply chains and transportation speeds. Problems in the food product supply chain, namely the value received by each member (suppliers, manufacturers and distributors) are still not balanced, especially at the upstream level, especially breeders, which is the starting point of the supply chain, obtaining low value. This indicates that the performance of the supply chain of cow's milk products is still low, but it should be noted also the competitive advantages that run the supply chain activities. This study wants to know the effect of supply chain integration on competitive advantage through supply chain performance. This research is quantitative research using the partial least square (PLS-SEM) method. The population in this study is cattle ranchers in West Bandung Regency The results of this study can explain the competitive advantages that are influenced by supply chain integration through supply chain performance.
\end{abstract}

Keyword. stock products, supply chain, competitive advantage

\begin{abstract}
Abstrak.Produk peternakan khususnya susu sapi memiliki kendala terkait mudah rusak, sehingga memerlukan penanganan yang lebih. khususnya dalam rantai pasokan dingin dan kecepatan transportasi. Masalah dalam rantai pasokan produk pangan yaitu nilaiyang diterima masing - masing anggota (supplier, manufaktur dan distributor) masih belum seimbang terutama di tingkat upstream khususnya peternak yang menjadi titik awal dari rantai pasokan memperoleh value yang rendah. Hal ini mengindikasikan akan kinerja rantai pasokan produk susu sapi masih rendah, tetapi perlu diperhatikan juga Keunggulan kompetitif yang menjalankan aktivitas rantai pasokan tersebut. Kajian ini ingin mengetahui pengaruh integrasi rantai pasokan terhadap keunggulan bersaing melalui kinerja rantai pasokan. Penelitian ini bersifat penelitian kuantitatif dengan menggunakan metode partial least square (PLS-SEM). Populasi pada penelitian ini yaitu peternak sapi di di Kabupaten Bandung Barat Hasil dari penelitian ini dapat menjelaskan keunggulan bersaing yang dipengaruhi integrasi rantai pasokan melalui kinerja rantai pasokan.
\end{abstract}

Kata Kunci. produk peternakan, rantai pasokan, keunggulan bersaing

Correspondence.yunyun@lecture.unjani.ac.id.

History of article. Received: Oktober 2018, Revision: Januari 2019, Published: Maret 2019

\section{PENDAHULUAN}

Perbaikan ketahanan pangan di Indonesia diharapkan mampu menyelaraskan struktur perekonomian nasional, mempercepat pertumbuhan ekonomi nasional, mengurangi tingkat pengangguran terbuka, menurunkan tingkat kemiskinan, mendominasi sektor riil dan memperbaiki pemerataan pendapatan masyarakat. Sehingga dapat memberikan kesejahteraan bagi masyarakat Indonesia.

Salah satu minuman yang bergizi tinggi yaitu susu sapi. Susu sapi merupakan salah satu bahan pangan yang sangat penting bagi pemenuhan kebutuhan gizi masyarakat. Susu sapi berperan sebagai asupan penting untuk kesehatan, kecerdasan, dan pertumbuhan, khususnya anak-anak

Konsumen susu sapi sangat bervariasi, mulai dari bayi, anak-anak, remaja dan dewasa menjadikan produk susu merupakan produk yang memiliki pasar yang sangat luas. Pada 2011 konsumsi susu di Indonesia mencapai 12,85 liter per kapita per tahun, meningkat dibandingkan 2010 yaitu 11,95 liter. Meskipun terjadi peningkatan jumlah, konsumsi susu di Indonesia masih lebih rendah dibandingkan sejumlah negara di Asia, seperti Malaysia (50,9 liter), India (47,1 liter), Singapura (44,5 liter), Thailand $(33,7$ liter), Vietnam (14,3 liter), dan Filipina (13,7 liter) Yun dan Kurniawan (2016). 
Integrasi rantai pasokan menjadi tema utama dalam menciptakan nilai (Cao and Zang dalam Zhu, 2018). Peningkatan produktivitas dalam rantai pasokan produk pangan dapat jika anggota rantai pasokan melakukan integrasi di jaringan rantai pasokannya. Seperti yang disampaikan oleh (Cheng, et al. 2016) Integrasi eksternal memiliki hubungan yang signifikan dengan kinerja operasi dari jaringan manufaktur, sedangkan integrasi internal tidak berhubungan. Dari hasil penelitian tersebut integrasi eksternal memiliki hubungan yang signifikan dengan kinerja operasi.

Integrasi eksternal memiliki hubungan yang signifikan dengan kinerja operasi dari jaringan manufaktur, sedangkan integrasi internal tidak berhubungan. Aturan yang ketat, kebutuhan konsumen untuk transparency, dan aturan internal CEO terkait internal value dapat mempengaruhi bisnis untuk mempertimbangkan keberlangsungan prioritas keunggulan (Neutzling, et al , 2018)

Permasalahan dalam kemampuan bersaing dari produk pangan di Jawab Barat, salah satunya dikarenakan masih relatif mahalnya bahan baku yang harus dibeli. Selain itu kualitas dari produk pangan yang ada masih lebih rendah dari produk impor. Sehingga daya saing dari sisi harga menjadi kurang. Mahalnya harga bahan baku yang dibutuhkan dikarenakan relatif panjangnya rantai pasokan dari produk pangan. Selain itu, produk pangan yang gampang rusak membuat pengiriman yang dilakukan harus dijalankan dengan cepat. Sehingga dapat menjalankan proses yang efisien.

Industri pengolahan produk pangan di Jawa Barat semakin berkembang dan memunculkan para pelaku di sektor pangan dengan variasi produk yang semakin tinggi (bapeda.jabarprov.go.id). Permasalah dalam produk pangan salah satunya lebaranya rantai pasokan pangan mulai dari supplier sampai dengan konsumen sehingga biaya yang dikeluarkan menjadi tidak efisien. Selain itu, produk pangan memiliki kapasitas yang besar dalam melakukan distribusinya sehingga tingkat kehilangan produk mencapai $20 \%$ mulai dari pemasok sampai dengan konsumen.
Total impor susu sapi dari beberapa negara mencapai US\$ 54,64 juta sepanjang Januari 2014.Sedangkan beratnya sebesar 12,09 juta kilogram (kg)dari jumlah impor tersebut ada lima negara pemasok terbesar susu sapi ke Tanah Air, yakni Amerika Serikat (AS), Australia, Selandia Baru, Belgia, dan Kanada

Produk susu impor sangat dominan bukan hanya karena kurangnya produksi, tetapi dari kualitas susu lokal yang masih kurang. Pada dasarnya standar untuk kualitas susu yang baik. Untuk memperoleh susu sapi yang berkualitas, harus didapat dari sapi yang berkualitas pula, sehingga untuk dapat meningkatkan kualitas susu sapi, harus di tingkatkan juga kualitas dari pada sapi perah yang ada di Indonesia sehingga kualitas susu yang di hasilkan dapat memenuhi standar yang baik.

Variabel supply chain integration dan competitive advantage menunjukan adanya pengaruh negatif yang signifikan antara supply chain integration terhadap competitive advantage Swink and Song (2007).

Perusahaan manufaktur yang lebih menekankan pada supplier integration mungkin dapat meningkatkan perbaikan kualitas, tetapi perusahaan dalam meningkatkan kualitas dengan supplier integration akan lebih lambat dibandingkan dengan pesaing yang mungkin melakukan investasi di area lain, misalnya menjalakan integrasi internal perusahaan. Perusahan dengan supplier integration juga menyebabkan perusahaan kurang terbuka terhadap kesempatan yang ada pada supplier yang belum dikenal maupun supplier sebelumnya, hal ini juga menimbulkan switching cost jika ingin mengambil kesempatan

Integrasi rantai pasokan harus mempertimbangkan tingkat strategis, taktis dan operasional. Supply Chain Integration dapat didefinisikan sebagai sejauh mana anggota Supply Chain mencapai pengelolaan antar dan intra-organisasi kolaboratif pada tingkat aktivitas strategis, taktis dan operasional (dan aliran fisik dan informasinya yang sesuai), yang dimulai dengan pemasok bahan baku, memberi nilai tambah pada produk untuk memenuhi kebutuhan pelanggan akhir dengan biaya 
terendah dan kecepatan terbesar (Luque, et al 2014).

Permasalahan dalam kemampuan bersaing dari produk pangan di Jawab Barat, salah satunya dikarenakan masih relatif mahalnya bahan baku yang harus dibeli. Selain itu kualitas dari produk pangan yang ada masih lebih rendah dari produk impor. Sehingga daya saing dari sisi harga menjadi kurang. Mahalnya harga bahan baku yang dibutuhkan dikarenakan relatif panjangnya rantai pasokan dari produk pangan. Selain itu, produk pangan yang gampang rusak membuat pengiriman yang dilakukan harus dijalankan dengan cepat. Sehingga dapat menjalankan proses yang efisien.

Sumber daya yang berwujud dan tidak berwujud yang diinvestasikan dalam jaringan rantai pasokan bisa diintegrasikan degan jaringan informasi melalui kemitraan rantai pasokan. Lebih spesifiknya, rutinitas informasi formal dan informal membutuhkan waktu dan tenaga untuk mengembangkan kemungkinan integrasi dari alur informasional melalui rantai pasokan perusahaan. Investasi dalam aset yang lebih spesifik dan orientasi jangka panjang dalam hubungannya memungkinkan pengembangan interaksi rutin.

Kabupaten Bandung Barat menjadi salah satu wilayah yang menghasilkan susu sapi yang baik. Produk susu segar yang diproduksi mayoritas di kirim ke Industri besar, kurang dari $10 \%$ dari hasil susu sapi yang dihasilkan diolah menjadi produk jadi. Sehingga para peternak kurang mendapatkan manfaat yang optimal dari produksi susu sapinya.

Para peternak sapi perah yang memproduksi susu segar perlu mendapat dukungan agar tercipta ketahanan pangan yang baik terutama di wilayah Kabupaten Bandung Barat. Integrasi penting bagi petani dan peternak karena adanya saling ketergantungan sehingga mengakibatkan ketidak seimbangan antara supply dan demand dari produk pangan.

Tujuan yang ingin di capai dari penelitian ini untuk menganalisis pengaruh integrasi rantai pasokan terhadap keunggulan bersaing yang diharapkan dapat menyelesaikan permasalahan dalam koordinasi dan intergrasi rantai pasok serta keunggulan bersaing pada koperasi perternak sapi di Kabupaten Bandung Barat.
Hasilnya diharapkan mampu memberikan jawaban atas permasalahan yang terjadi pada koordinasi, integrasi rantai pasok dan keunggulan bersaing.

\section{KERANGKA PENELITIAN \& HIPOTESIS}

\section{Supply Chain Integration}

SCM berfokus pada gerakan yang efisien waktu sumber daya dan integrasi dari berbagai fungsi dan tekanan yang menyesuakan dengan sumber daya Plenert (2014). Integrasi dilatarbelakangi oleh adanya keadaan saling ketergantungan. Ketergantungan dengan pihak luar organisasi dengan porsi yang semakin meningkat membuat perusahaan harus mengintegrasikan kegiatan dengan mitra dan rantai pasokan sehingga lebih efektif dalam menyampaikan produk ke pasar (Das, et all, 2006) .

Supply Chain integration merupakan seperangkat praktis untuk mendukung proses bisnis melalui lintas perusahaan, sangat berhubungan dengan effort untuk mengatasi ketidakpercayaan antar organisasi $\mathrm{He}$, et all (2013).

Pengembangan intergrasi Supply Chain adalah komponen dari produksi keseluruhan internasional, operasi, logistik, dan strategi distribusi. Intergasi pemasok sebagai adanya kesatuan antara pemasok, pembelian dan konstituen manufaktur dari sebuah organisasi. Intergrasi pemasok diwujudkan melalui kegiatankegiatan yang melibatkan kombinasi internal pembelian manufaktur dan eksternal terkait inisiatif pemasok (Das, et all, 2006). Beberapa alasan untuk integrasi internal pembelianmanufaktur yang mengkooptasi kedalam lingkup interagasi pemasok yaitu "co makership" suatu realita yang berkembang dengan tren outsourcing, menganggap pemasok sebagai perpanjangan dari pabrik, mempertimbangkan kontinuitas end-to-end antara produksi, pembelian dan pemasok.

Provider pembelian sebagai penghubung kritis antara manufaktur dan basis pemasok, keduannya menafsirkan dan mengkomunikasikan perencanaan produk dan kebutuhan produksi kepada pemasok dan bersamaan dengan penyediaan saluran untuk manufaktur agar tetap mengetahui teknologi, 
kapabilitas dan keterbatasan dari pemasok (Das, et all, 2006).

MenurutStadler, et all (2015) Integrasi mengacu pada susunan atau kerangka khusus yang menyebabkan perusahaan berkolaborasi dalam jangka panjang. Sehingga integrasi harus memilih anggota rantai pasokan yang mampu memberikan value bagi rantai pasokan secara keseluruhan.

Proses integrasi meliputi aktivitas memperoleh, berbagi, dan menggabungkan pengetahuan strategis dan arus informasi yang menghubungkan dan mengkoordinasi pihak eksternal organisasi yang berkaitan langsung (Flynn, et all (2010).

Dimensi Integrasi Rantai Pasokan yang terdiri dari Hubungan dengan Pelanggan, Pertukaran informasi melalui jaringan, Penggunaan Sistem Komputerisasi, Pembagian Informasi Pasar, Pembagian Informasi ketersediaan Produk, Proses pengelolaan Pemenuhan Pesanan, Tingkat Keluhan Pelanggan, Evaluasi Kepuasan Pelanggan.

\section{Kinerja Rantai Pasokan}

Kinerja rantai pasokan dan kinerja pemasok Kinerja rantai pasokan telah dikonseptualisasikan dengan berbagai cara (Vaart dan Donk dalam Zhang, 2015), sebagai ukuran kinerja keuangan dan / atau operasional agregat tunggal, dan mengacu pada pembeli dan / atau pemasok. Di sini, kinerja pemasok dianggap sebagai variabel hasil bunga karena kita fokus pada hubungan pembeli-pemasok. Kinerja pemasok telah banyak diteliti, khususnya dalam konteks program pengembangan pemasok.

Kinerja rantai pasokan dapat diukur dengan metode SCOR (Supply Chain Operations Reference). SCOR model telah dikembangkan pada tahun 1996 oleh Supply Chain Council (SCC). Ini bertujuan untuk menganalisis empat dimensi: keandalan kinerja komersial, fleksibilitas / responsif, biaya rantai pasokan dan omset modal komitmen

\section{Keunggulan Bersaing \\ "Competitive advantage is powerful idea, but it's extremely important to recognize that competitive advantage is a means to an end in}

itself'(Peter, 2010). Peter menjelaskan bahwa keunggulan bersaing ide yang penuh kekuatan tapi yang utama yaitu mengenali keunggulan bersaing berati sebagai alat untuk mencapai tujuan itu sendiri. Selain itu, Thompson dalam AlRfou and Trawneh (2010) Keunggulan bersaing sebagai kemampuan dari sebuah organisasi untuk lebih meningkatkan nilai bagi pelanggan lalu dibandingkan pesaing memiliki posisi relatif menguntungkan, tantangannya mempertahankan setiap keunggulan untuk sebuah capaian. Penjelasan tersebut menyatakan bahwa keunggulan bersaing diperoleh ketika mengimplementasikan strategik menciptakan nilai yang tidak dilakukan secara simultan oleh pemain lain yang ada dan pemain potensial.

Sedangkan menurut $\mathrm{Li}$, et all (2006) Competitive advantage is one factor that an organization is able to create a state of defense against competitors and includes a feature that allows an organization to distinguish itself from its competitors. Dimana berdasarkan pendapat $\mathrm{Li}$, et all (2006) Keunggulan kompetitif sebagai sebuah faktor yang ada pada sebuah organisasi untuk menciptakan ruang yang dapat menahan serangan kompetitor dan termasuk yang dilakukan perusahaan untuk mengalahkan pesaingnya.

Pesaingan dalam industri sangatlah dinamis. Seiring dengan adanya perubahan lingkungan yang semakin cepat, membuat persaingan semakin ketat. Banyak cara dalam memperoleh keunggulan bersaing perusahaan, dalam jangka pendek memang daya saing perusahaan dapat diperoleh dari strategi biaya rendah maupun strategi differensiasi (Poter, 2008). Dalam jangka panjang daya saing perusahaan hanya dapat dicapai dengan melakukan inovasi dan perbaikan secara berkesinambungan. Best (2010) mendefiniskan keunggulan bersaing sebagai keunggulan atas pesaing yang didapatkan dengan menyampaikan nilai pelanggan yang lebih besar, melalui harga yang lebih murah atau dengan menyediakan lebih banyak manfaat yang sesuai dengan penetapan harga yang lebih tinggi

Tracey, et all dalam Thatte, et all (2013)

"argues that competitive advantage comprises of 
distinctive competencies that sets an organization apart from competitors, thus giving them an edge in the marketplace". Keunggulan kompetitif serangkaian kompetensi khas/unik yang di oleh organisasi dibanding pesaing, yang memberikan mereka keunggulan di pasar. Keunggulan kompetitif sebagai kekuatan dari keunikan sebuah organisasi dibandingkan dengan pesaing agar dapat memperoleh keunggulan di pasar sasaran. Pendapat tersebut sejalan dengan pendapat Porter, dalam Thatte (2013)Competitive advantage centers on a firm's ability to be a low cost producer in its industry, or to be unique in its industry in some aspects that are popularly valued by customers. Porter menjelaskan bahwa inti dari keunggulan kompetitif merupakan kemampuan perusahaan untuk memproduksi dengan biaya yang rendah di industri tersebut atau menjadi unik di industri tersebut pada beberapa aspek yang populer sehingga memberikan nilai bagi konsumen.

Dalam mengembangkan keunggulan bersaing yang berkesinambungan saat ini semakin sulit. Keunggulan bersaing yang diperoleh dapat cepat menghilang. Perusahaan dapat mempertahankan keunggulan bersaing sampai layanan yang mereka berikan dan pola bagaimana mereka menyampaikannya memiliki atribut sesuai dengan kriteria sejumlah pelanggan (Horngren,et all, 2000).

Dalam memberikan nilai lebih kepada pelanggan perusahaan harus memperhatikan beberapa dimensi dari competitive advantage/keunggulan bersaing. Ukuran dalam menilai ketercapaian dari keunggulan bersaing sangat diperlukan untuk mengetahui sejauh mana perusahaan memiliki keunggulan bersaingnya di bandingkan dengan pesaingnya.

Dari definisi para ahli di atas, dapat disimpulkan bahwa keunggulan kompetitif atau keunggulan bersaing merupakan kemampuan yang dimiliki oleh suatu perusahaan dalam memberikan nilai lebih kepada pelanggan dibandingkan dengan pesaingnya.

\section{Dimensi Keunggulan Bersaing}

Keunggulan bersaingmenurut Heizer et all (2016) ditandai dengan faster response to the customer at lower cost and higher quality". Sedangkan menurut Dranoveand Whitedalam
Diab (2013) terdapat empat dimensi dalam competitive advantage yaitu cost, flexibility, delivery, and quality. Sementara Hosseini (2012) mengemukakan bahwa keunggulan bersaing adalah keinginan manajemen yang kuat dalam menguasai : biaya (cost), mutu (quality), waktu (time) dimana pencapaian nilai pelanggan dalam rangka untuk menciptakan dan mempertahankan keunggulan bersaing erat hubungannya dengan aktivitas-aktivitas yang dilakukan oleh perusahaan.

The five dimensions of competitive advantage construct used in this study are:

Price/Cost. Kemampuan dari sebuah organisasi untuk dapat bersaing dengan kompetitor berdasarkan harga yang rendah.

Quality. Kemampuan perusahaan untuk menawarkan kualitas produk dan kinerja yang membuat nilai yang lebih tinggi bagi konsumen.

Deliver dependability. Kemampuan dari organisasi untuk menyediakan waktu, tipe dan jumlah dari produk yang dipesan konsumen.

Product innovation. Kemampuan dari organisasi untuk memperkenalkan produk baru dan fiturnya ke pasar

Time to market. Kemampuan dari organisasi untuk memperkenalkan produk baru lebih cepat dari pada kompetitor utama.

Hipotesis dari penelitian ini yaitu terdapat pengaruh integrasi rantai pasokan melalui kinerja rantai pasokan terhadap keunggulan bersaing pada peternak sapi perah di Kabupaten Bandung Barat.

\section{METODE PENELITIAN}

Menurut tingkat eksplanasinya (level of explanation), penelitian ini dikelompokkan ke dalam penelitian deskriptif dan asosiatif. Penelitian asosiatif merupakan hubungan dan pengaruh satu variabel terhadap variabel lainnya

Dipertegas dengan pendapat Riduan (2010) penelitian deskriptif asosiatif adalah penelitian yang dilakukan untuk mengetahui nilai variabel mandiri, sedangkan penelitian asosiatif merupakan penelitian yang bertujuan untuk mengetahui hubungan atau pengaruh antara dua variabel atau lebih. Dari penelitian asosiatif akan dibangun suatu teori yang dapat berfungsi untuk menjelaskan, meramalkan dan mengontrol suatu gejala atau fenomena. 
Fokus penelitian ini adalah untuk mengetahui seberapa besarnya pengaruh koordinasi, dan intergrasi rantai pasokan terhadap keunggulan bersaing produk pangan di Kabupaten Bandung Barat. Penelitian ini memiliki tujuan dimana penulis ingin mengetahui persepsi para petani dan peternak yang tergabung dalam koperasi ataupun Gapoktan mengenai koordinasi dan integrasi rantai pasokan serta pengaruhnya terhadap keunggulan bersaing. Tujuan yang ingin dicapai dari penelitian ini untuk mengetahui pengaruh koordinasi, dan intergrasi rantai pasokan terhadap keunggulan bersaing

Varaibel pada penelitian ini yaitu Integrasi Rantai Pasokan (X1), Integrasi Rantai Pasokan (X2) dan Keunggulan Bersaing (Y). Koordinasi rantai pasokan diukur dengan dimensi pertukaran informasi sederhana, informasi yang diformulasikan, dan kerjasama yang dimodelkan. Integrasi rantai pasokan diukur dengan dimensi hubungan dengan pelanggan, pertukaran informasi melalui jaringan, Pembagian informasi pasar, pembagian informasi kertersediaan produk, proses pengelolaan pemenuhan pasar dan tingkat keluhan pelanggan serta evaluasi kepuasan pelanggan. Keunggulan Bersaing diukur dengan dimensi harga, Kualitas, pengriman dan respon terhadap pasar. Skala ukur yang digunakan menggunakan interval.

Populasi dalam penelitian ini adalah petani dan peternak yang tergabung dalamKoperasi dan GAPOKTAN (gabungan kelompok tani) di Kabupaten Bandung Barat. Sampel adalah bagian dari populasi dan merupakan anggota populasi yang terseleksi. Adapun sampling adalah suatu proses seleksi terhadap sejumlah elemen yang memadai dari populasi. Agar sampel dapat digeneralisasi ke populasi, maka teknik penarikan sampel dilakukan secara acak (random), sehingga setiap anggota populasi memiliki peluang yang sama untuk dipilih menjadi sampel. Penarikan sampel secara acak tersebut merupakan sampling probabilitas (probability sampling) dari sampel tersebut dipilih sampel yang memenuhi kriteria dari peneliti (statisfied random sampling).

Dalam penelitian ini data yang dihasilkan berupa persepsi, sikap atau pendapat. Untuk mengukur persepsi tersebut skala yang digunakan adalah skala Likert.

Kegiatan-kegiatan dalam mengolah data adalah sebagai berikut: 1) Editing, memeriksa daftar pertanyaan yang telah diserahkan oleh para pengumpul data. 2) Coding, mengklasifikasikan jawaban-jawaban dari para responden ke dalam kategori- kategori.3) Tabulasi, pekerjaan membuat tabel. Jawabanjawaban yang sudah diberi kode kategori jawaban kemudian dimasukkan dalam tabel.4)Verifikasi, pemeriksaaan benar tidaknya hasil survai yang telah dilakukan.

Langkah yang tak kalah penting dalam rangka kegiatan pengumpulan data adalah melakukan pengujian terhadap instrumen (alat ukur) yang akan digunakan. Kegiatan pengujian instrumen penelitian meliputi dua hal, yaitu pengujian validitas dan reliabilitas

Untuk menganalisis data kualitatif melalui analisis kualitatif dan kuantitatif. Dalam analisis deskriptif, setiap variabel dikategorikan menjadi empat (4) kategori hasil pengukuran, yaitu : sangat rendah, rendah, sedang, tinggi. Setiap kategori dihitung frekuensi dan proporsinya serta disusun distribusinya. Kategorisasi dilakukan dengan meninjau posisi skor total variabel dalam batas-batas nilai minimal, kuartil I, median, kuartil III dan maksimal yang dapat dicapai sebagai berikut (Riduwan, 2010):

Minimal $\leq$ skor total < Kuartil I: Sangat Rendah

Kuartil I $\leq$ skor total < Median: Rendah

Median $\leq$ skor total <Kuartil III: Sedang

Kuartil III $\leq$ skor total < Maksimal : Tinggi

Untuk menjawab pertanyaan asosiatif, yang ingin mengetahui hubungan koordinasi, integrasi rantai pasok dan keunggulan bersaing menggunakan Partial Least Square Structuere Equation Modeling (PLS-SEM). Keunggulan penerapan analisis verifikatif dengan menggunakan PLS-SEM dapat menggunakan sampel kecil ataupun sampel besar serta sebagai penelitian eksploratori dan mampu menjelaskan variabel laten (Widarjono, 2014)

Elemen dalam analisis jalur PLS-SEM pada gambar 3.1 yaitu inner model dan outer model. Inner model digambarkan hubungan anak panah antar variabel laten independen (X1 dan X2) dan variabel dependen $(\mathrm{Y})$. Outer model ditunjukan 
oleh hubungan anak panah antar variabel laten baik dependen maupun independen dan indikator. Outer model terdiri dari dua pengukuran yaitu model pengukuraan reflektif dan normatif.Dalam mengukur jalur PLS-SEM menggunakan program SMARTPLS 3.

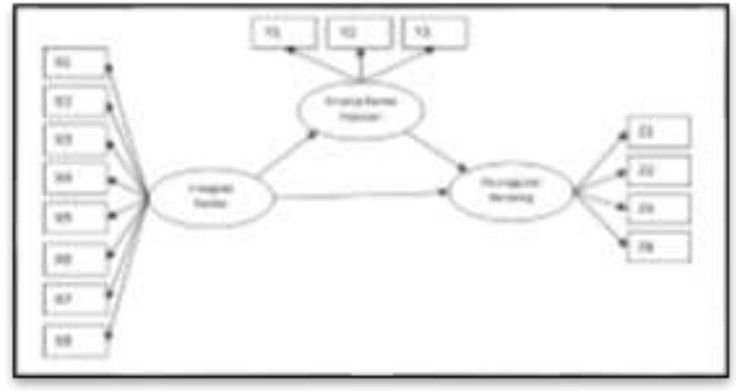

Gambar 1. Model PLS SEM

\section{Evaluasi Outer Model Reflektif}

Evaluasi outer model bertujuan untuk mengevaluasi variabel indikator. Model pengukuran variabel laten di dalam PLS-SEM ada dua yaitu model reflektif dan model formatif.

Evaluasi model reflektif terdiri dari (Widarjono, 2014);

1. Indicator reliability. Di dasarkan pada outer loading, jika nilai outer loading lebih tinggi dari 0,7 maka variabel indikator perlu dipertahankan untuk uji teori, sedangkan untuk pengujian eksplorasi antara 0,7-0,5. Dan bila kurang dari 0,5 maka variabel indikator harus dihilangkan.

2. Discriminat validity. Menggunakan dua metode, cross loading variabel. Variabel indikator terhadap variabel laten harus lebih besar dibanding variabel laten lain.

3. Internal consistency. Composite reliability digunakan untuk mengukur konsistensi internal. Pengujian uji teori nilainya harus lebih besar 0,5.

4. Convergent validity. Convergent Variance Extracted (AVE), digunakan untuk mengukur Convergent validity. Nilai AVE harus lebih besar dari 0,5.

\section{Evaluasi Inner Model (Model Struktural)}

1. Signifikansi dan besarnya pengaruh variabel laten independen

Uji ini untuk mengetahui apakah variabel laten independen mempengaruhi variabel laten dependen, melalui uji t. Serta melakukan evaluasi masing-masing variabel laten independen dengan melihat nilai koefisien jalur (path cofficient).

2. Koefisien Determinasi R2
Koefisien determinasi mengukur seberapa besar variasi variabel laten dependen dijelaskan oleh variabel laten independen.

\section{HASIL DAN PEMBAHASAN}

Hasil dan pembahasan pada penelitina ini akan mejelaskan analisis deskriptif integrasi rantai pasokan, kinerja rantai pasokan dan keunggulan bersaing produk susu sapi pada peternak sapi perah di kabupaten Bandung Barat. Hasil penelitian ini berdasarkan jawaban responden yaitu peternak sapi perah.

Integrasi rantai pasokan disajikan pada tabel berikut:

Tabel 1. Kategorisasi Integrasi rantai Pasokan Produk Susu Sapi pada Peternak Sapi Perah di Kabupaten Bandung Barat

\begin{tabular}{|c|c|c|}
\hline DIMENSI & $\begin{array}{l}\text { RATA- } \\
\text { RATA }\end{array}$ & KATEGORI \\
\hline $\begin{array}{l}\text { Hubungan Dengan } \\
\text { Pelanggan }\end{array}$ & 3,12 & Sedang \\
\hline $\begin{array}{l}\text { Pertukaran Informasi } \\
\text { melalui Jaringan }\end{array}$ & 3,21 & Sedang \\
\hline $\begin{array}{l}\text { Penggunaan Sistem } \\
\text { Komputerisasi }\end{array}$ & 3,17 & Sedang \\
\hline $\begin{array}{l}\text { Pembagian Informasi } \\
\text { Pasar }\end{array}$ & 3,50 & Tinggi \\
\hline $\begin{array}{l}\text { Pembagian Informasi } \\
\text { Ketersediaan Produk }\end{array}$ & 3,41 & Tinggi \\
\hline $\begin{array}{l}\text { Proses Pengelolaan } \\
\text { Pemenuhan Pesanan }\end{array}$ & 3,16 & Sedang \\
\hline $\begin{array}{l}\text { Tingkat Keluhan } \\
\text { Pelanggan }\end{array}$ & 3,18 & Sedang \\
\hline $\begin{array}{l}\text { Evaluasi Kepuasa } \\
\text { Pelanggan }\end{array}$ & 3,35 & Sedang \\
\hline
\end{tabular}

Sumber : Kuesioner, diolah kembali 2018

Berdasarkan tabel di atas, integrasi rantai pasokan, terlihat bahwa terdapat dua dimensi yang memiliki skor dengan kategori tinggi yaitu Pembagian informasi pasar dan Pembagian Informasi ketersediaan produk. Dimensi lain yang membentuk integrasi rantai pasokan berada pada kategori sedang. Sehingga peternak sapi masih harus mampu meningkatkan dimensi hubungan dengan pelanggan, Pertukaran informasi melalui jaringan, penggunaan sistem terkomputerisasi, Proses pengelolaan pemenuhan pesanan dan tingkat keluhan pelanggan serta evaluasi pelanggan, sehingga secara keseluruhan Integrasi Rantai Pasokan berada pada Kategori Sedang. 
Selanjutnya dijelaskan analisis dari kinerja rantai pasokan produk susu sapi pada peternak sapi perah di Kabupaten Bandung Barat. Hasilnya disajikan pada tabel berikut.

Tabel 2. Kategorisasi Kinerja Rantai Pasokan

\begin{tabular}{ccc}
\hline DIMENSI & RATA-RATA & KATEGORI \\
PLAN & 3.15 & SEDANG \\
SOURCE & 3.38 & SEDANG \\
MAKE & 2.97 & RENDAH \\
DELIVERY & 3.31 & SEDANG \\
RETURN & 3.16 & SEDANG \\
\hline
\end{tabular}

\section{Sumber : Kuesioner, diolah kembali 2018}

Berdasarkan tabel di atas, kinerja rantai pasokan pada peternak sapi perah di Kabupaten Bandung Barat, berada pada kategori cukup. Hanya saja pada dimensi Make (proses produksi) masih berada pada kategori sedang, sedangkan dimensi lainnya berada pada kategori sedang. Sehingga, kinerja rantai pasokan peternak sapi perah di Kabupaten Bandung Barat masih harus ditingkatkan.

Kinerja rantai pasokan yang berada pada kategori sedang, memperlihatkan masih perlu adanya upaya dalam meningkatkan kinerja rantai pasokan sehingga manfaat yang diterima oleh peternak dapat lebih optimal.

Selanjutnya dijelaskan hasil pengolahan data berdasarkan kuesioner terkait keunggulan bersaing produk susu sapi pada peternak sapi perah di Kabupaten Bandung Barat. Hasilnya disajikan pada tabel berikut.

Tabel 3. Kategorisasi Keunggulan Bersaing produk susu sapi pada peternak sapi perah di kabupaten Bandung Barat

\begin{tabular}{lcc}
\hline \multicolumn{1}{c}{ DIMENSI } & RATA-RATA & KATEGORI \\
\hline RESPON & 3.32 & SEDANG \\
BIAYA & 3.63 & TINGGI \\
KUALITAS & 3.28 & SEDANG \\
PENGIRIMAN & 3.30 & SEDANG
\end{tabular}

Sumber :Kuesioner, diolah kembali 2018

Berdasarkan tabel 4.3 keunggulan bersaing produk susu sapi pada peternak sapi perah di Kabupaten Bandung Barat secara umum berada pada kategori sedang. Dari keempat dimensi yaitu respon, biaya, kualitas dan pengiriman, biaya berada pada kategori tinggi, artinya memiliki tingkat keunggulan bersaing yang relatif baik.
Kategori respon, kualitas dan pengiriman masih berda pada kategori sedang sehingga masih harus di tingkatkan. Sehingga perlu untuk meningkatkan keunggulan bersaing produk susu sapi pada peternak sapi perah di Kabupaten Bandung Barat.

Berdasarkan jawaban responden, harga jual produk susu sapi yang diproduksi peternak sapi di Kabupaten Bandung Barat cukup kompetitif. Oleh karena itu perlu meningkatkan dimensi lainnya agar keunggulan yang dimiliki dapat diperoleh lebih komperhensif.

Model Penelitian Keunggulan bersaing produk susu sapi perah yang dipengaruhi integrasi rantai pasokan melalui kinerja rantai pasokan produk susu sapi pada peternak sapi perah di Kabupaten Bandung Barat.

Model ini merupakan model kuantitatif dengan pendekatan partial least square (PLS) structure equation modeling (SEM). Berdasakan hasil pengolahan data dengan pendekatan PLSSEM menggunakan alat bantuSMARTPLS, diperoleh hasil pengolahan data sebagai berikut

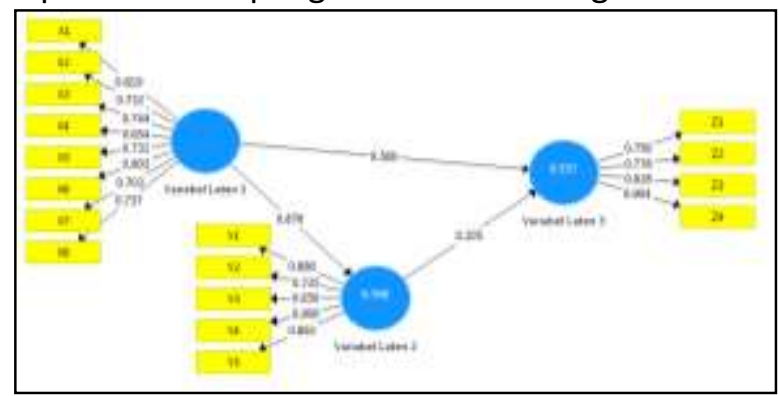

Gambar2. Model Keunggulan bersaing produk susu sapi perah yang dipengaruhi integrasi rantai pasokan melalui kinerja rantai pasokan produk susu sapi pada peternak sapi perah di Kabupaten Bandung Barat proses bootstraping

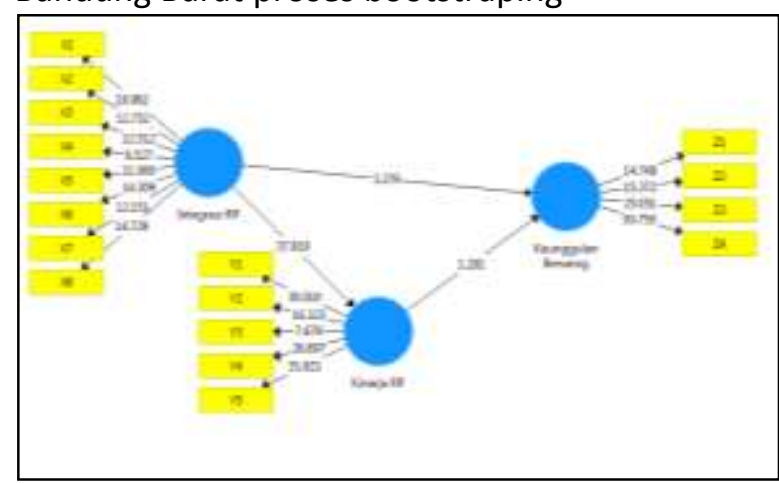

Gambar 3. ModelKeunggulan bersaing produk susu sapi perah yang dipengaruhi integrasi rantai pasokan melalui kinerja rantai pasokan produk 
susu sapi pada peternak sapi perah di Kabupaten Bandung Barat Proses Alogarim

\section{Evaluasi Model}

Evaluasi Model PLS-SEM menggunakan evaluasi outer model dan inner model. Evaluasi outer model yang bertujuan untuk mengevaluasi variabel indikator. Evaluasi Outer Model terdiri dari Indicator reliability, discriminant validity, internal consistency dan convergent validity. Sedangkan evaluasi inner model menjelaskan pengaruh variabel koordinasi dan integrasi rantai pasokan terhadap keunggulan bersaing.

Tabel 4. Outer Loading

\begin{tabular}{cccc}
\hline DIMENSI & $\begin{array}{c}\text { Integrasi } \\
\text { Rantai } \\
\text { Pasokan }\end{array}$ & $\begin{array}{c}\text { Kinerja } \\
\text { RP }\end{array}$ & $\begin{array}{c}\text { Keunggulan } \\
\text { Bersaing }\end{array}$ \\
\hline X1 & 0,819 & & \\
X2 & 0,732 & & \\
X3 & 0,744 & & \\
X4 & 0,654 & & \\
X5 & 0,732 & & \\
X6 & 0,803 & & \\
X7 & 0,703 & & \\
X8 & 0,737 & & \\
Y1 & & 0,886 & \\
Y2 & & 0,735 & \\
Y3 & & 0,650 & \\
Y4 & & 0,900 & \\
Y5 & & 0,892 & \\
Z1 & & & 0,756 \\
Z2 & & & 0,778 \\
Z3 & & & 0,828 \\
Z4 & & & 0,904 \\
\hline
\end{tabular}

Sumber : Kuesioner, diolah kembali 2018

Berdasarkan nilai outer loading, nilai outer loading masing-masing dimensi memiliki nilai outer loading lebih dari 0,5 artinya semua dimensi dapat digunakan untuk membentuk outer model masing-masing variabel laten.

Tabel 5. Forner Larcker.

\begin{tabular}{lccc}
\hline & $\begin{array}{c}\text { Integrasi } \\
R P\end{array}$ & $\begin{array}{c}\text { Kinerja } \\
\text { Rantai } \\
\text { Pasokan }\end{array}$ & $\begin{array}{c}\text { Keunggulan } \\
\text { Bersaing }\end{array}$ \\
\hline $\begin{array}{l}\text { Integrasi } \\
\text { Rantai } \\
\begin{array}{l}\text { Pasokan } \\
\text { Kinerja }\end{array}\end{array}$ & 0,742 & & \\
$\begin{array}{l}\text { Rantai } \\
\text { Pasokan } \\
\text { Keunggulan } \\
\text { Bersaing }\end{array}$ & 0,740 & 0,818 & \\
\hline
\end{tabular}

Sumber : Kuesioner, diolah kembali 2018
Berdasarkan hasil perhitungan Forner Larcker seluruh variabel laten memiliki nilai yang lebih tinggi dibandingkan dengan variabel laten lainnya. Berdasarkan hasil perhitungan tersebut, model penelitian yang diembangkan memenuhi syarat dari discriminat validity.

Internal Consistency

Tabel 6. Composite Reliability

\begin{tabular}{lc}
\hline & $\begin{array}{c}\text { Composite } \\
\text { Reliability }\end{array}$ \\
\hline Integrasi Rantai Pasokan & 0,907 \\
Kinerja Rantai Pasokan & 0,890 \\
Keunggulan Bersaing & 0,909 \\
\hline
\end{tabular}

Sumber : Kuesioner, diolah kembali 2018.

Berdasarkan tabel composite reliablity, untuk menguji konsistensi internal, keseluruhan variabel yang diukur memiliki nilai lebih dari 0,7. Sehingga model yang di buat mampu memenuhi syarat dari composite reliability dalam membentuk model yang konsisten.

Convergent Validity

Dalam mengukur covergent validity, digunakan nilai average variance validity. Hasilnya disajikan pada tabel berikut.

Tabel 7. Evaluasi Average Variance Extracted (AVE)

\begin{tabular}{lc}
\hline \multicolumn{1}{c}{ KONSTRUK } & F-SQUARE \\
\hline Integrasi Rantai Pasokan & 0,551 \\
Kinerja Rantai Pasokan & 0,671 \\
Keunggulan Bersaing & 0,670 \\
\hline
\end{tabular}

Sumber: Kuesioner, diolah kembali 2018

Berdasarkan tabel Average Variance Extracted (AVE) menunjukan memiliki nilai AVE diatas 0,5 artinya semua outer model untuk penelitian ini valid sehingga tidak perlu adanya penghilangan indikator.

\section{Nilai Koefisien Jalur}

Hasil dari proses bootstrapping dalam SmartPLS menghasilkan koefisien jalur hubungan antara variabel supply chain management, variabel kinerja koperasi dan variabel strategi operasi.

Selain itu hasil bootstrapping juga memperlihatkan koefisien hubungan variabel laten dengan dimensinya. 
Tabel 8. 8efisien Jalur Variabel Penelitian

\begin{tabular}{|c|c|c|c|}
\hline KONSTRUK & $\begin{array}{l}\text { Original } \\
\text { Sampel }\end{array}$ & $\begin{array}{c}\text { T- } \\
\text { Statistic }\end{array}$ & P Value \\
\hline $\begin{array}{c}\text { Integrasi RP } \rightarrow \text { Keunggulan } \\
\text { Bersaing }\end{array}$ & 0,740 & 12.825 & 0,000 \\
\hline Integrasi RP $\rightarrow$ Kinerja RP & 0,876 & 37,919 & 0,000 \\
\hline $\begin{array}{c}\text { Kinerja RP } \rightarrow \text { Keunggulan } \\
\text { Bersaing }\end{array}$ & 0,205 & 1,291 & 0,197 \\
\hline Integrasi RP $\rightarrow \mathrm{X} 1$ & 0,178 & 12,785 & 0,000 \\
\hline Integrasi RP $\rightarrow$ X2 & 0,171 & 9,916 & 0,000 \\
\hline Integrasi RP $\rightarrow$ X3 & 0,192 & 10,180 & 0,000 \\
\hline Integrasi RP $\rightarrow$ X4 & 0,137 & 7,763 & 0,000 \\
\hline Integrasi RP $\rightarrow$ X5 & 0,155 & 9,472 & 0,000 \\
\hline Integrasi RP $\rightarrow$ X6 & 0,158 & 10,342 & 0,000 \\
\hline Integrasi RP $\rightarrow$ X7 & 0,187 & 9,745 & 0,000 \\
\hline Integrasi RP $\rightarrow$ X8 & 0,170 & 9,742 & 0,000 \\
\hline Kinerja RP $\rightarrow$ Y1 & 0,232 & 18,126 & 0,000 \\
\hline Kinerja RP $\rightarrow$ Y2 & 0,280 & 11,718 & 0,000 \\
\hline Kinerja RP $\rightarrow$ Y3 & 0,233 & 9,953 & 0,000 \\
\hline Kinerja RP $\rightarrow$ Y4 & 0,253 & 12,998 & 0,000 \\
\hline Kinerja RP $\rightarrow$ Y5 & 0,235 & 18,382 & 0,000 \\
\hline Keunggulan Bersaing $\rightarrow \mathrm{Z1}$ & 0,257 & 9,497 & 0,000 \\
\hline Keunggulan Bersaing $\rightarrow \mathrm{Z2}$ & 0,333 & 11,508 & 0,000 \\
\hline Keunggulan Bersaing $\rightarrow$ Z3 & 0,280 & 9,972 & 0,000 \\
\hline Keunggulan Bersaing $\rightarrow$ Z4 & 0,348 & 12,723 & 0,000 \\
\hline
\end{tabular}

Sumber :Kuesioner, Diolah Kembali 2018

Dari tabel di atas terlihat bahwa semua dimensi berpengaruh signifikan terhadap variabel latennya. Berdasarkan nilai koefisien jalur di atas, maka hubungan model antar variabel dapat diungkapkan kedalam persamaan struktural. Tetapi, diperlukan variabel residual terlebih dahulu.

Adapun hasil variabel residual dihitung berdasarkan nilai $R$ Square dan Ajusted $R$ Square. Hasilnya dapat dilihat pada tabel berikut.

Tabel 9. Nilai $R$ square dan nilai $R$ Square Adjusted

\begin{tabular}{|c|c|c|c|}
\hline Konstruk & $\begin{array}{c}R \\
\text { Square }\end{array}$ & $\begin{array}{c}R \text { Square } \\
\text { Ajusted }\end{array}$ & $\begin{array}{c}\text { Variabel } \\
\text { Residual } \\
\text { (V(1-R } \\
\text { Square) }\end{array}$ \\
\hline $\begin{array}{l}\text { Keunggulan } \\
\text { Bersaing }\end{array}$ & 0,557 & 0,547 & 0,673 \\
\hline $\begin{array}{l}\text { Kinerja Rantai } \\
\text { Pasokan }\end{array}$ & 0,768 & 0,765 & 0,874 \\
\hline
\end{tabular}

Sumber: Kuesioner, Diolah Kembali 2018.

Model konstruk yang menghubungkan antara variabel Integrasi rantai pasokan dan Teknologi Informasi terhadap Keunggulan Bersaing dapat diungkap dengan persamaan struktural sebagai berikut.

$$
Y=0,557 X+0,673
$$

Persamaan (1) mengindikasikan besarnya koefisien dari Integrasi Rantai Pasokan dan terhadap Keunggulan Bersaing adalah 0,547 dengan 0,673 sebagai nilai variabel residual.

Pengaruh Integrasi Rantai Pasokan dan Teknologi Informasi terhadap Keunggulan bersaing $54,7 \%$ merupakan hubungan langsung dari supply chain managment melalui kinerja rantai pasokan terhadap Keunggulan Bersaing. Sedangkan

\section{Korelasi Antar Variabel}

Hasil dari proses PLS Alogaritm dengan menggunakan SmartPLS menghasilkan korelasi antar variabel dari variabel yang diukur dalam penelitian ini dapat dilihat pada tabel sebagai berikut.

Tabel 10. Nilai Korelasi Antar Variabel

\begin{tabular}{ccc}
\hline KONSTRUK & $\begin{array}{c}\text { Keunggulan } \\
\text { Bersaing }\end{array}$ & $\begin{array}{c}\text { Kinerja } \\
\text { Rantai } \\
\text { Pasokan }\end{array}$ \\
\hline $\begin{array}{c}\text { Integrasi } \\
\text { Rantai Pasokan } \\
\text { Kinerja Rantai } \\
\text { Pasokan }\end{array}$ & 0,560 & 0,876 \\
\hline
\end{tabular}

Sumber : Kuesioner, diolah kembali 2018

Dari model struktural dan nilai korelasi dapat diperoleh informasi mengenai besarnya pengaruh langsung dan tidak langsung suatu variabel.

Berdasarkan nilai koefisien jalur pada tabel 4.16 Integrasi Rantai Pasokan memiliki hubungan yang positif terhadap Keunggulan Bersaing sebesar $43 \% \%$. Teknologi Informasi terhadap keunggulan bersaing memiliki tingkat hubungan $16,8 \%$.

\section{Evaluasi $\boldsymbol{R}$-Square $\left(\mathbf{R}^{2}\right)$}

Setelah menguji validitas dari outer model selanjutnya pengujian model struktural. Pengujian model struktural dilakukan untuk menilai hubungan antara varibel laten dalan model, melihat dari nilai $R$ Square. Nilai $R$ Square yang diperoleh dari perhitungan dengan menggunakan bantuan SmartPLS. Hasil dapat dilihat dari tabel berikut. 
Tabel 11. Evaluasi R Square

\begin{tabular}{ccc}
\hline & & Adjusted R \\
Konstruk & R Square & Square \\
\hline Keunggulan Bersaing & 0,557 & 0,547 \\
Kinerja RP & 0,768 & 0,765 \\
\hline
\end{tabular}

Sumber : Kuesioner, diolah kembali 2018

Sesuai dengan kriteria pengukuran model sebagaimana dikemukakan Chin (dalam Ghozali, 2011) tentang baik, moderat atau lemahnya model, maka nilai Rsquare sebesar 0,557 dan 0,547 menunjukkan bahwa struktur yang terbangun dalam penelitian ini adalah moderat.

Nilai $R$ Square dalam tabel di atas, dapat dijelaskan bahwa variabilitas konstruk nilai Keunggulan bersaing pada usaha kecil bidang makanan dan minuman sebesar $55,7 \%$ dapat dijelaskan oleh variabel Integrasi rantai pasokan dan Teknologi informasi sisanya 44,3\% dapat dijelaskan oleh variabel lain diluar faktor-faktor yang diteliti.

\section{Evaluasi Effect Size $\left(\mathbf{f}^{2}\right)$}

Tabel 12. Evaluasi effect Size $\left(f^{2}\right)$

\begin{tabular}{|c|c|c|}
\hline KONSTRUK & F-Square & \\
\hline Integrasi RP $\rightarrow$ Keunggulan Bersaing & 12.825 & Besar \\
\hline Integrasi RP $\rightarrow$ Kinerja RP & 37,919 & Besar \\
\hline Kinerja RP $\rightarrow$ Keunggulan Bersaing & 1,291 & Besar \\
\hline Integrasi RP $\rightarrow$ X1 & 12,785 & Besar \\
\hline Integrasi RP $\rightarrow$ X2 & 9,916 & Besar \\
\hline Integrasi RP $\rightarrow$ X3 & 10,180 & Besar \\
\hline Integrasi RP $\rightarrow$ X4 & 7,763 & Besar \\
\hline Integrasi RP $\rightarrow$ X5 & 9,472 & Besar \\
\hline Integrasi RP $\rightarrow$ X6 & 10,342 & Besar \\
\hline Integrasi RP $\rightarrow$ X7 & 9,745 & Besar \\
\hline Integrasi RP $\rightarrow$ X8 & 9,742 & Besar \\
\hline Kinerja RP $\rightarrow$ Y1 & 18,126 & Besar \\
\hline Kinerja RP $\rightarrow \mathrm{Y} 2$ & 11,718 & Besar \\
\hline Kinerja RP $\rightarrow$ Y3 & 9,953 & Besar \\
\hline Kinerja RP $\rightarrow$ Y4 & 12,998 & Besar \\
\hline Kinerja RP $\rightarrow$ Y5 & 18,382 & Besar \\
\hline Keunggulan Bersaing $\rightarrow$ Z1 & 9,497 & Besar \\
\hline Keunggulan Bersaing $\rightarrow$ Z2 & 11,508 & Besar \\
\hline Keunggulan Bersaing $\rightarrow \mathrm{Z3}$ & 9,972 & Besar \\
\hline Keunggulan Bersaing $\rightarrow \mathrm{Z4}$ & 12,723 & Besar \\
\hline
\end{tabular}

Sumber: Kuesioner, diolah kembali 2018

Pada tabel 12. memperlihatkaneffect size dari model pada penelitian ini. Hasilnya memperlihatkan bahwa pengaruh yang tinggi dari setiap variabel dengan pengaruh besar.

\section{KESIMPULAN}

Integrasi Rantai Pasokan pada Peternak Sapi perah di Kabupaten Bandung Baratterdiri dari delapan sub variabel yaitu hubungan dengan pelanggan, pertukaran informasi melalui jaringan, penggunaan sistem terkomputerisasi, pembagian infomasi pasar, pembagian informasi ketersediaan produk, proses pengelolaan pesanan, tingkat keluhan pelanggan dan evaluasi kepuasan pelanggan. Integrasi rantai pasokan terkategori Cukup baik, meskipun pembagian infomasi pasar dan pembgaian informasi ketersediaan produk terkategori baik.

Keunggulan Bersaing yang diukur dengan empat sub variabel yaitu respon konsumen, biaya, kualitas dan pengiriman terkategorisasi cukup baik. Teknologi Informasi dapat diukur oleh ketiga sub variabel, sedangkan integrasi rantai pasokan diukur dengan delapan sub variabel.

Model keunggulan bersaing yang dibangun menunjukan bahwa keunggulan bersaing dipengaruhi integrasi rantai pasokan melalui kinerja rantai pasokan produk susu sapi pada peternak sapi perah di Kabupaten Bandung Barat secara signifikan.

\section{REKOMENDASI}

Penelitian terkait manajemen rantai pasokan masih perlu dilakukan untuk meningkatkan khasanah keilmuan dibidang rantai pasokan. Selain itu penelitian di pada objek produk pangan perlu ditingkan kualitasnya untuk memberikan manfaat guna kesejahteraan masyarakat yang lebih baik.

Diharapkan penelitian terkait manajemen rantai pasokan khususnya bagaimana upaya membangun model rantai pasokan yang optimal dapat diteliti lebih lanjut sehingga manfaat yang diperoleh dan perkembangan ilmu dapat semakin baik.

\section{DAFTAR PUSTAKA}

Adebambo, Somuyiwa. Mcisn Mcilt., Toyin, Adebayo. 2012.Firm's Competitiveness through Supply Chain Responsiveness and Supply Chain Management Practices in Nigeria. British Journal of Arts and Social Sciences ISSN: 2046-9578, Vol.10 No.I (2012) 
Al-Rfou and Trawneh. 2010. To What Extent Can a Company Achieve a Competitive Advantage Through Job Development? Kamla-Raj 2010 J Soc Sci, 23 (3):189-196 (2010)

Agha and Alrubaiee. 2012. Effect of Core Competence on Competitive Advantage and Organization Performance. International Journal of Business Management Vol 7, No 1; January 2012 192 ISSN.

Arvitrida, Ninite I. Tako, Antuela. Robertson, Duncan. Robinson, Stewart. 2016. Duration Of Collaboration From A Market Perspective: An Agent-Based Modeling Approach. International Conference on Operations and Supply Chain Management, Phuket

Best, Roger J.2000. Market Base Management: Strategic for Growing Customer Value and Profit. Prentice Hall. New Jersey

Chopra, Sunil. Meindl, Peter. Supply Chain Management Strategy, Planning and Operation. Pearson.

Das, Ajay. Narasimhan, Ram. Talluri, Srinivas.2006. Supplier integration finding an optimal configuration. Journal of Operations Management 24 (5), 563582.

Droge, Cornelia. Vickery, Shawnee K. Jacobs, Mark A. 2012. Does supply chain integration mediate the relationships between product/process strategy and service performance? An empirical study. Int. J. Production Economics 137 (2012) 250-262. Elsevier

Flynn, B B.Huo, Baofeng. Zhao, Xiande. 2010. The impact of supply chain integration on performance: A contingency and configuration approach. Journal of Operations Management. Volume 28, Issue 1, January 2010, Pages 58-71. Elsevier

Diab. 2013. Using the Competitive Dimensions to Achieve Competitive Advantage (A Study on Jordania Private Hospitals. International Journal of Academia Research in Business and Social Sience. July 2013. Vol 3 No 7 ISSN: 2222-699
Gassmann, Oliver. Kausch, Christoph. Enkel, Ellen. 2010. Negative side effects of customer integration. Int. J. Technology Management, Vol. 50, No. 1, 2010. Inderscience Enterprises Ltd.

He, Yuanqiong. Lai Kin Keung. Sun, Hongyi. Chen, Yun. 2013. The impact of supplier integration on customer integration and new product performance: The mediating role of manufacturing flexibility under trust theory. Int. J. Production Economics. Elsevier

Heizer and Render. 2016. Operation Management: Sustainability and Supply Chain Management-Eleventh Edition. Pearson Education : England.

Hosseini, Seyed Mahmood. Azizi, Shahriar. Sheikhi, Narges.2012. An Investigation on the Effect of Supply Chain Integration on Competitive Capability: An Empirical Analysis of Iranian Food Industry. International Journal of Business and Management Vol. 7, No. 5; March 2012

Horngren, Charles T, George Foster Srikant M Datar. 2000, Cost Accounting : A Managerial Emphasis. International Edition

Karimi, Ebrahim. Rafiee, Mahmoud. 2014. Analyzing the Impact of Supply Chain Management Practices on Organizational Performance through Competitive Priorities (Case Study: Iran Pumps Company). International Journal of Academic Reaserch in Accounting, Finance, and Management Science. Vol 4. No 1 January 2014, pp. 1-15

Kocolu, Ipek. Imamoglu, Salih Zeki. Ince, Hüseyin. Keskin, Halit. 2011. The effect of supply chain integration on information sharing: Enhancing the supply chain performance. rocedia Social and Behavioral Sciences 24 (2011) 1630-1649. Elsevier.

Lambert, Douglas M. Schwieterman, Matthew A. Supplier relationship management as a macro business process. Supply Chain Management: An International Journal, Vol. 17 Iss 3 pp. $337-352$

Li, Suhong. Nathan, Bhanu Ragu. Nathan, T.S. Ragu. Rao, S. Subba. 2006. The impact of 
supplychain management practices on competitive advantage and organizational performance. Omega : The International Journal of Management Science 34 (2006) 107 124

Neutzling, Daiane Mülling. Land, Anna Stefan Seuring, Luis Felipe Machado do Nascimento. 2018. Linking sustainabilityoriented innovation to supply chain relationship integration. Journal of Cleaner Production 172 (2018) 34483458

Peter. 2010. The CEO, Strategy, and Shareholder .Value : Making The Choices That Maximize Company Performance. Jhon Wiley and Son.

Plenert, Gerhard J. 2014. Supply Chain Optimization through Segmentation and Analytics. CRC Press.

Porter, M.E. 1998. The Competitive Advantage: Creating and Sustaining Superior Performance. NY. Free Press.

Quan Zhu, Harold Krikke, Marjolein Caniels, "Supply chain integration: value creation through managing inter-organizational learning", International Journal of Operations \& Production Management. https://doi.org/10.1108/IJOPM-062015-0372

Riduwan. 2010. Dasar-dasar Statiska. Bandung: Alfabeta.

Shiraz, Mohammad Ali Enayati. Ramezani, Elham. 2014. Impact of Supply Chain Management Strategies On Competitive Advantage In Manufacturing Companies Of Khuzestan Province. Singaporean Journal Of Business Economics, And Management Studies Vol.2, No.11, 2014

Simatupang, Togar M. Sridharan, Ramaswami. 2005. An integrative framework for supply chain collaboration. The International Journal of Logistics Management Vol. 16 No. 2, 2005 pp. 257-274

Stadtler, Hartmut. Meyr, Herbert. Kilger, Christoph. 2015. Supply Chain Management and Advanced Planning: Concept, Models, Software, and Case Studies. Fifth edition. Springer.
Sudirman, Yuddy Krisna. Wiyono, Heru. Hendra. Maseleno, Andino. 2005. ANALISIS Kuantitatif Mengenai Bullwhip Effect Dengan Menggunakan Konsep Supply Chain Management untuk Meningkatkan Performansi Sistem Distribusi. Prosiding Seminar Nasional Manajemen Teknologi I ISBN : 979-99302-0-0.

Sugiyono.2010.Metedoe Penelitian Bisnis: Pendekatan Kuantitatif, Kualitatif dan R\&D. Bandung,

Sukati, Inda. Hamid, Abu Bakar Abdul. Baharun, Rohaiza. Alifiah, Mohd Norfian. Anuar, Melati Ahmad. 2012.Competitive Advantage through Supply Chain Responsiveness and Supply. International Journal of Business and Commerce Vol. 1, No. 7: Mar 2012[01-11]

Swaminathan, Jayashankar M. Tayur, Sridhar R. 2003. Tactical Planning Models for Supply Chain Management. A.G. de Kok and S.C. Graves, Eds., Handbooks in OR \& MS, Vol. 112003 Elsevier.

Swink, Morgan. Dan Song, Michael. 2007. Effects of marketing-Manufacturing integration on new product development time and competitive advantage. Journal of Operations Management 25 (2007) 203217. Elsevier

Thatte, Ashish A. Rao, Subba S. Nathan, T. S. Ragu. 2013. Impact of SCM practices of A Firm On Supply Chain Responsiveness And Competitive Advantage of A Firm. The Journal of Applied Business Research - March/April 2013 Volume 29, Number 2

Venus, Klaus. 2014. Supply Chain ManagementPart of Strategic Management. Journal of Business and Economics, ISSN 21557950, USA July 2014, Volume 5, No. 7, pp. 1052-1067

Voigt, Guido. 2011. Supply Chain Coordination in Case of Asymmetric Information : Information Sharing and Contracting in a just in timeEnvironment. Springer.

bapeda.jabarprov.go.id

Widarjono, Agus. 2015. Analisis Multivariat Terapan. Yogyakata. UPP STIM YKPN

Yun, Yun dan Kurniawan, Asep. 2016. Pengaruh Pengendalian Kualitas Susu Sapi 
terhadap Keunggulan Bersaing Produk Susu Sapi pada Peternak Sapi Perah di Kecamatan Parongpong dan Kecamatan Lembang Kabupaten Bandung Barat. Portofolio Vol. 13 mei 2016 : 38 -57. ISSN : 1829-7188. 